\title{
EFFECT OF SOIL CONDITIONING ON THE MOISTURE CONTENT AND THE SALT PROFILE OF THE SOIL UNDER IRRIGATION WITH SALINE WATER
}

\author{
JÓZSEF ZSEMBELI ${ }^{* *}$, LÚCIA SINKA ${ }^{1}$, ARZU RIVERA-GARCÍA', KRISZTINA CZELLÉR ${ }^{1}$, \\ GÉZA TUBA ${ }^{1}$, KOLOMAN KRIŠTOF$^{2}$, PAVOL FINDURA ${ }^{2}$
}

\author{
${ }^{1}$ Research Institute of Karcag Institutes for Agricultural Research and Educational Farm University of \\ Debrecen, Hungary \\ ${ }^{2}$ Slovak University of Agriculture in Nitra, Slovak Republic
}

\begin{abstract}
ZSEMBELI, J. - SINKA, L. - RIVERA-GARCÍA, A. - CZELlÉR, K. - TUBA, G. - KRIŠTOF, K. - FINDURA, P.: Effect of soil conditioning on the moisture content and the salt profile of the soil under irrigation with saline water. Agriculture (Polnohospodárstvo), vol. 65, 2019, no. 2, pp. $77-87$.
\end{abstract}

\begin{abstract}
The research work was started on the preliminary knowledge that the risk of secondary salinization is high in the hobby gardens around Karcag as the water of the aquifers used for irrigation is saline, nevertheless irrigation in the drought periods is essential for vegetable production. A complex experiment was set up in 12 simple drainage lysimeters at the lysimeter station of the Research Institute of Karcag in 2012 in order to simulate the conditions of irrigation characteristic in the region with the goal of finding a solution to mitigate the harmful effects by means of optimization of irrigation. In 2017-2018 three approaches were applied for the scientific establishment of the problem studying the effect of different irrigation frequencies, different irrigation water qualities, and soil conditioning on the moisture content and the salt profile of the soil. The soil conditioner (Neosol) applied was found to have a positive effect on the water and salt regime of the soil, partly by creating a more favourable vertical distribution of the soil water, and partly preserving more moisture in the soil.
\end{abstract}

Key words: lysimeter, Neosol, secondary salinization, irrigation regime, water quality

There are extended agricultural areas in the world that can be utilised only with irrigation for crop production, nevertheless salt affection, erosion, and other physical degradation processes can be induced by the application of irrigation. Therefore, the scientific establishment of irrigation in a soil-plant system has been started in several countries with the involvement and support of different international organisations (FAO, UNESCO, World Bank) (Bardaji 1974).
The accumulation of salts can be a big problem during germination. In the top soil layer higher salinity can be found that may be influenced by the depth and spacing of the tape, and pre-seasonal irrigation. Salt accumulation in the soil can be expected when irrigation is practiced under water limiting conditions (Enciso et al. 2002). Plant yield and quality could be negatively affected if the salts which are transported to the root zone are accumulated here. The salt concentration of the irrigation water or the

Zsembeli József (*Corresponding author), Sinka Lúcia, Rivera-García Arzu, Czellér Krisztina, Tuba Géza, Research Institute of Karcag Institutes for Agricultural Research and Educational Farm University of Debrecen, H-5300 Karcag, Kisújszállási út 166, Hungary. E-mail: zsembeli@agr.unideb.hu Krištof Koloman, Findura Pavol, Faculty of Engineering Slovak University of Agriculture in Nitra, Slovak Republic 
groundwater at high salinity may be the most important factor of salinity in the root zone. Irrigation water starts to reduce with evaporation and plant usage after being kept in the soil. Unfortunately most of the salts that are transmitted remain in the soil at this time (Kaman et al. 2017). Population is growing really quickly, thus the land and water resources cannot sustain them; prime farmland and fresh water have been already fully utilized. It is obvious that bringing salt-affected land and water resources into production is suggested (Abdul \& Mahmood 2012).

In the Great Hungarian Plain approximately 400,000 ha is the area where secondary salinization has occurred, mainly due to the rise of the level of salty groundwater. Blaskó (2005) monitored the salt and water balance of irrigated areas and found the increase of salt content of the soil in several cases. During the 1980' and $1990^{\prime}$ ' on $30 \%$ of the studied area increasing soil salt content could be detected, especially on the susceptible areas where the soil can be only potentially irrigated due to the high salt content in their deeper layers.

Saline soils are characterised by poor plant growth and low microbial activity. It is important to understand the response of soil microbial communities to changes in soil salinity (Asghar et al. 2012). Active substances, like in soil conditioners, have a broad spectrum of impact on processes responsible for soil fertility, as well as on plants. Moreover, they influence the optimal development of the biological, chemical and physical processes in the soil and plants (Borowiak et al. 2016) giving a chance of the mitigation of the harmful effects of salinity.

The research work was started on the preliminary knowledge that the risk of secondary salinization is high in the hobby gardens around Karcag as the water of the aquifers used for irrigation is saline, nevertheless irrigation in the droughty periods is essential for vegetable production (Zsembeli et al. 2011). We examined the possibility of a "soil friendly" optimization of irrigation if we take all these conditions given. Our hypothesis is that by the optimization of irrigation (site-specific frequency, dosage) combined with soil conditioning (better physical, chemical, and biological status of the soil) more favourable conditions can be created for the crops even under originally unfavourable circumstances.

The main objective of our study is to determine the correlations in a soil-water-plant system in order to understand the processes taking place during secondary salinization and to find solutions for this problem to mitigate the harmful effects, mainly by means of prevention. We consider optimization of irrigation the best preventive method if the unfavourable soil conditions (heavy textured clay soil susceptible to secondary salinization) and hydrological circumstances (saline irrigation water, high climatic water shortage) are given. Three approaches are applied for the scientific establishment of the problem studying the effect of:

- different irrigation frequencies,

- different irrigation water qualities,

- soil conditioning

on the moisture content and the salt profile of the soil, and through that, on the water supply of the indicator plant that can be manifested in the morphological parameters and the yields of the plants. As the final aim of our research is the optimization of irrigation for soils endangered by secondary salinization we have chosen beans (Phaseolus vulgaris L. var. nanus) as an indicator crop, which is commonly grown in the hobby gardens. It has high water demand and relatively poor salt tolerance.

Though our experiment is very complex, in this paper our results gained by studying the effect of soil conditioning are described only. The aim of the application of the Neosol soil conditioner is to improve the soil characteristics by unblocking the nutrients in the soil and making them available to plants (Sulewska et al. 2016). Soil, where Neosol was applied, showed a higher moisture level, especially in the $0.25-0.3 \mathrm{~m}$ soil depth. It could be a result of a better capillary porosity of soil which is responsible for storing soil water, which is really important for crops growing on heavy soils.

\section{MATERIAL AND METHODS}

\section{Experimental location lysimeters}

For the scientific establishment of our examinations, we set up a complex experiment in 12 simple drainage lysimeters (Figure 1) in the lysimeter station of the Research Institute of Karcag (RIK), Institutes for Agricultural Research and Education- 
al Farm, University of Debrecen ( $4^{\circ} 29^{\prime}$, E $20^{\circ}$ 56 '). The lysimeters are $1.5 \mathrm{~m}$ deep with a drain pipe at $1.2 \mathrm{~m}$ and have a surface area of $0.8 \mathrm{~m}^{2}$. Simple drainage lysimeters are very suitable to quantify the amount of salts leached from the soil column (Blaskó \& Zsembeli 2008).

The lysimeters are filled with a slightly sodic meadow solonetz soil. The main soil parameters of the investigated soil were determined according to the Hungarian standards in the accredited laboratory of RIK (Table 1).

\section{Irrigation regimes}

The effect of two treatments is analysed in a complex way in this paper: irrigation with two different qualities of water and soil conditioning. All the lysimeters were irrigated with the same weekly amount of water (15 litres per week), 6 with saline water $(1,600 \mathrm{mg} / 1$ salt content $)$, and the other 6 with deionised water. The concentration of $1,600 \mathrm{mg} / \mathrm{l}$ was chosen as it is characteristic to the groundwater and the shallow wells utilizing the aquifers at $12-40 \mathrm{~m}$ depth in the area of Karcag.

Taking the surface area of the lysimeters into account, 1 litre of irrigation water equals $1.25 \mathrm{~mm}$ water input. The soil of 6 lysimeters was treated with a soil conditioner (Neosol), the other 6 did not get any chemical amendments. Hence 6 replications were applied for irrigation water quality as well as for soil conditioning. The combination of the treatments are summarised in Table 2.

The soil moisture content data were collected from $1^{\text {st }}$ September 2017 until $31^{\text {st }}$ August 2018 (12 months). We distinguished two seasons according to the presence of irrigation: the autumn-winter (AW) season lasting from $1^{\text {st }}$ September 2017 until $28^{\text {th }}$ February 2018 , and the spring-summer (SS) season lasting from $1^{\text {st }}$ March till $31^{\text {st }}$ August 2018, respectively. This way, the AW season is practically between two irrigation periods. This resolution is rational if we want to study the long term effect

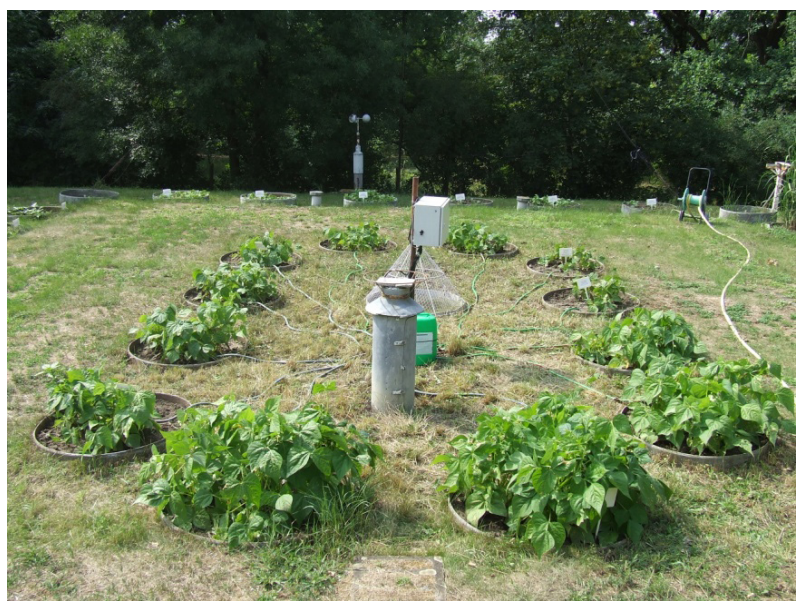

Figure 1. Simple drainage lysimeters used for the complex experiment

$\mathrm{T}$ a

Main soil parameters of the investigated soil

\begin{tabular}{|l|c|c|c|c|}
\hline \multicolumn{1}{|c|}{ Parameter } & Unit & Layer & Layer & Layer \\
$0-0.2 \mathrm{~m}$ & $0.2-0.4 \mathrm{~m}$ & $0.4 \mathrm{~m}$ \\
\hline $\mathrm{pH}_{(\mathrm{KCl})}$ & & 7.00 & 7.23 & 7.41 \\
Total soluble salt content* & {$[\%]$} & 0.13 & 0.12 & 0.13 \\
$\mathrm{Humus} \mathrm{content}$ & {$[\%]$} & 2.31 & 1.43 & 1.07 \\
$\mathrm{NO}_{3}-\mathrm{N}$ & {$[\mathrm{mg} / \mathrm{kg}]$} & 68.60 & 14.60 & 9.60 \\
$\mathrm{P}_{2} \mathrm{O}_{5}$ & {$[\mathrm{mg} / \mathrm{kg}]$} & $1,072.00$ & 653.00 & 307.00 \\
$\mathrm{~K}_{2} \mathrm{O}$ & {$[\mathrm{mg} / \mathrm{kg}]$} & 444.00 & 247.00 & 207.00 \\
$\mathrm{Ca}$ & {$[\mathrm{mg} / \mathrm{kg}]$} & $8,710.00$ & $19,080.00$ & $44,160.00$ \\
$\mathrm{Mg}$ & {$[\mathrm{mg} / \mathrm{kg}]$} & 813.00 & $1,722.00$ & $2,160.00$ \\
$\mathrm{Na}$ & {$[\mathrm{mg} / \mathrm{kg}]$} & 90.00 & 316.00 & 782.00 \\
\hline
\end{tabular}

*Total soluble salt content was calculated from electric conductivity (EC) 
of irrigation and to assess the soil moisture stocks available before the start of the irrigation season. Before the AW season irrigation was also applied (beans were grown as a second crop after sweet corn), $204 \mathrm{~mm}$ water was irrigated in 2017 according to the irrigation protocol (15 litres per week). In 2018, when we grew only beans, $192 \mathrm{~mm}$ water was irrigated in total.

\section{Soil conditioning}

The soil conditioner we applied in the experiment is Neosol (previously called PRP-SOL). According to the producer, Neosol is a soil conditioner formulated as concentrated premium quality pellets. Thanks to its MIP (Mineral Inducer Process) soil ingredients, Neosol boosts the biological activity of the soil and thus improves its fertility (I1). Some parameters of Neosol soil conditioner are summarised in Table 3.

The first application of Neosol in 6 of the simple drainage lysimeters of our irrigation experiment was on $30^{\text {th }}$ April of 2013 . We repeated the application every spring with the dose of $48 \mathrm{~g} / \mathrm{m}^{2}$ (480 $\mathrm{kg} / \mathrm{ha}$ ). This dose is higher than the recommended for field conditions, but the intensive irrigation justified the increased dosage (higher loss by leaching was ex- pected). The results described in this study originate from the $5^{\text {th }}$ and $6^{\text {th }}$ years of application.

\section{Soil moisture content measurements}

24 SMT 100 sensors by Umwelt-Geräte-Technik $\mathrm{GmbH}$ (Figure 2) inserted in the soil layers of $0-0.1$ and $0.2-0.3 \mathrm{~m}$ measured the soil moisture content $[\mathrm{v} / \mathrm{v} \%]$ and temperature $\left[{ }^{\circ} \mathrm{C}\right]$ with the measurement frequency of one hour. Due to its unique measuring principle, it combines the advantages of a low-cost FDR system with the accuracy of a TDR system, resulting in reliable measuring values even in clayey soils. It is compact and robust but also elastic and thus resistant design make the SMT-100 a durable, flexible and versatilely applicable measuring instrument (I2).

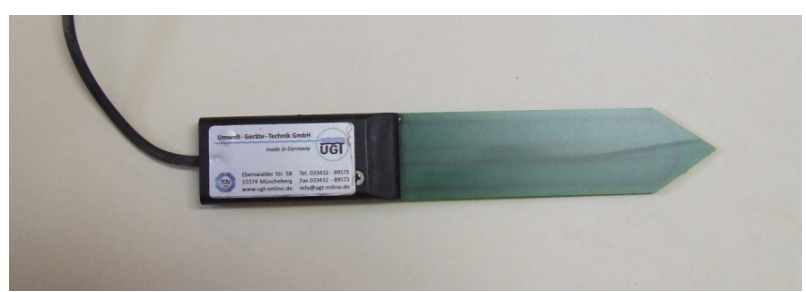

Figure 2. SMT-100 soil moisture probe

Source: I2

$\mathrm{T}$ a $\mathrm{b} 1$ e 2

Experimental design of the complex lysimeter experiment (Karcag, 2017, 2018)

\begin{tabular}{|c|c|c|c|}
\hline Lysimeter No. & Replication & $\begin{array}{c}\text { Application of } \\
\text { Neosol }\end{array}$ & Irrigation water \\
\hline 1 & 1 & + & deionised \\
2 & 2 & + & deionised \\
3 & 3 & + & salty well water \\
4 & 1 & + & salty well water \\
5 & 2 & salty well water \\
6 & 3 & - & salty well water \\
7 & 1 & - & salty well water \\
8 & 2 & - & salty well water \\
9 & 3 & - & deionised \\
10 & 1 & - & deionised \\
12 & 2 & & deionised \\
\hline
\end{tabular}


$\mathrm{T}$ a

Main parameters of Neosol

\begin{tabular}{|c|c|c|c|c|c|c|c|c|}
\hline $\mathrm{CaO}$ & $\mathrm{MgO}$ & $\mathrm{pH}$ & $\begin{array}{c}\text { Bulk } \\
\text { density }\end{array}$ & $\mathrm{Na}_{2} \mathrm{O}$ & $\mathrm{K}_{2} \mathrm{O}$ & $\mathrm{N}$ & $\mathrm{P}_{2} \mathrm{O}_{5}$ & Particle size \\
\hline $35 \%$ & $8 \%$ & 8 & $1.21 \mathrm{~kg} / \mathrm{m}^{3}$ & $4.5 \%$ & $0.7 \%$ & $0.3 \%$ & $0.03 \%$ & $<0.315 \mathrm{~mm}$ \\
\hline
\end{tabular}

Source: PRP Technologies

The soil moisture data were expressed in [mm] taking the following correlation into account:

$1 \mathrm{~mm}$ soil moisture stock $=1 \mathrm{v} / \mathrm{v} \%$ soil moisture content in a $0.1 \mathrm{~m}$ deep soil layer (Filep 1999). The measurement frequency was 1 hour, but only the daily averages of the soil moisture data are illustrated in this paper by ranking them into four water supply categories ('dry', 'sufficient', 'good' and 'wet') determined on the base of the water holding capacity of the investigated soil.

One-way analysis of variance (ANOVA) was used to compare the means of the soil moisture data representing the investigated treatments, periods and soil layers. Where a significant result from ANOVA was gained, the least significant difference $(L S D)$ was calculated.

\section{RESULTS}

Effect of soil conditioning on the soil moisture content

The soil moisture content results are analysed according to the investigated soil layers and seasons in order to figure out the relevant correlations and for the easier understanding.

The change of the sum of the soil moisture contents in the two investigated soil layers $(0-0.1$ and $0.2-0.3 \mathrm{~m}$ ) in the AW season in the function of soil conditioning is illustrated in Figure 3. The curves fit very well to each other, which means that no effect of the soil conditioner on the total water stocks of the upper $0.3 \mathrm{~m}$ deep soil layer could be figured out (the mean values are not significantly different). Nevertheless we found significant differences in the stratification of the moisture profile. The soil moisture content in the upper soil layer $(0-0.1 \mathrm{~m})$ was higher in the untreated control than in soil of the ly- simeters treated with Neosol $(L S D=0.48)$ almost along the entire AW season (Figure 4). Exactly the opposite correlation $(L S D=0.32)$ could be observed in the lower, 0.2-0.3 m deep layer (Figure 5). Due to irrigation and the natural precipitation of $343.5 \mathrm{~mm}$ in the AW season and the fact that only evaporation (no transpiration) decreased them, the soil moisture stocks were in the 'good' category in the lower investigated soil layer.

From $1^{\text {st }}$ March 2018 the SS season started, it is practically the continuation of the AW season hence the initial soil moisture contents originate from the previous season showing if the soil has water shortage or not. The change of the sum of the soil moisture contents in the two investigated soil layers $(0-0.1$ and $0.2-0.3 \mathrm{~m}$ ) in the SS season in the function of soil conditioning is illustrated in Figure 6. The difference was found to be significant $(L S D=0.55)$.

Contrary to the AW season, during the SS season higher moisture content was characteristic to the soil treated with soil conditioner. The difference did not come from the moisture content of the top layer as we detected quite similar values (the mean values are not significantly different) for the treated and the untreated lysimeters as well (Figure 7). Significant difference $(L S D=1.49)$ could be figured out in the lower soil layer: during the SS season the average soil moisture content was 20\% higher where Neosol was applied resulting in 'good' water supply along the season, contrary to the control soil where the water supply of the plants was in the 'sufficient' category in the second half of the investigated period (Figure 8).

\section{Effect of soil conditioning on the salt profile of the soil}

The effect of soil conditioning was examined not only on the soil moisture content, but in close rela- 


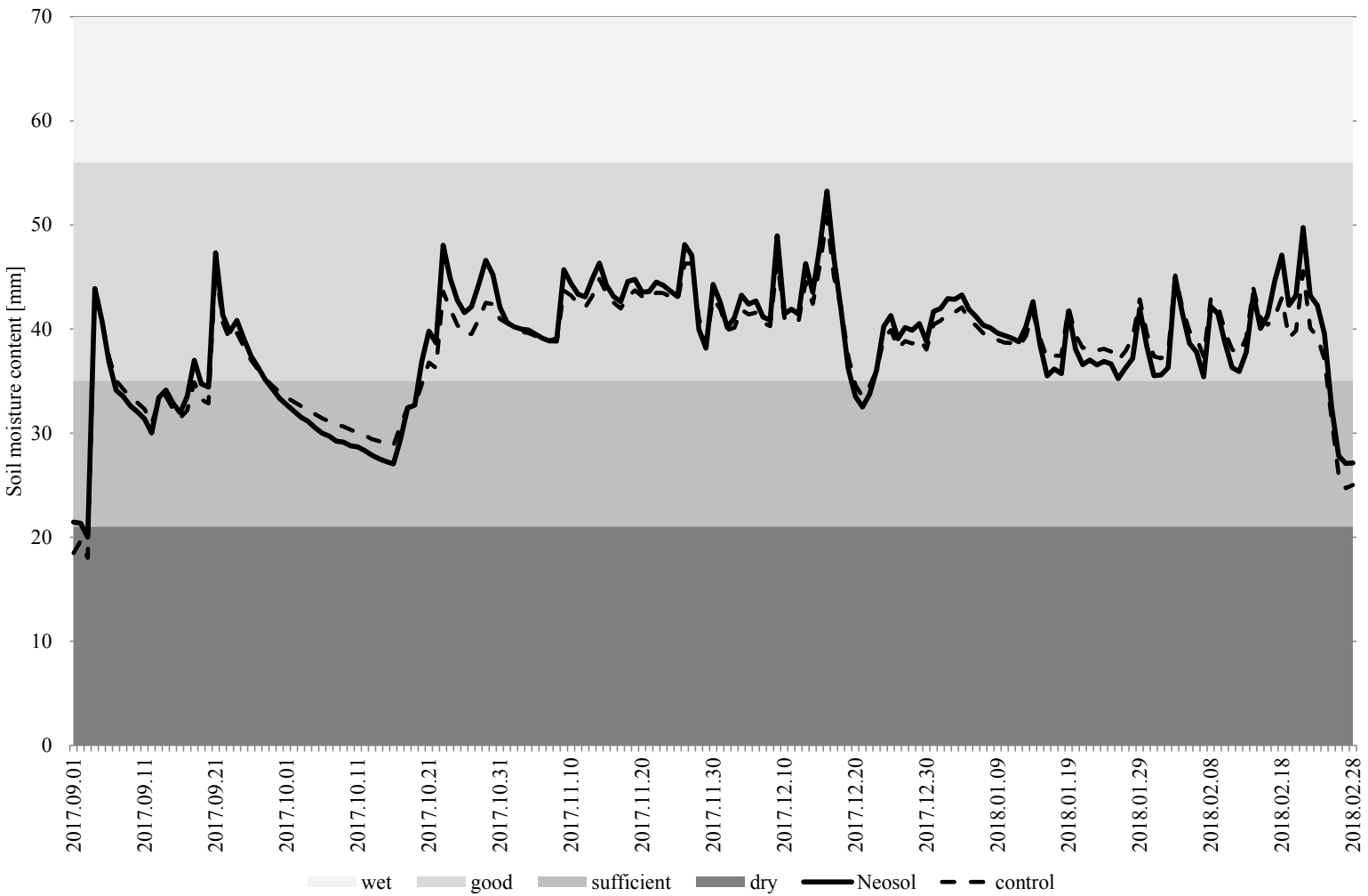

Figure 3. The sum of the soil moisture stocks of the two investigated soil layers in the AW season

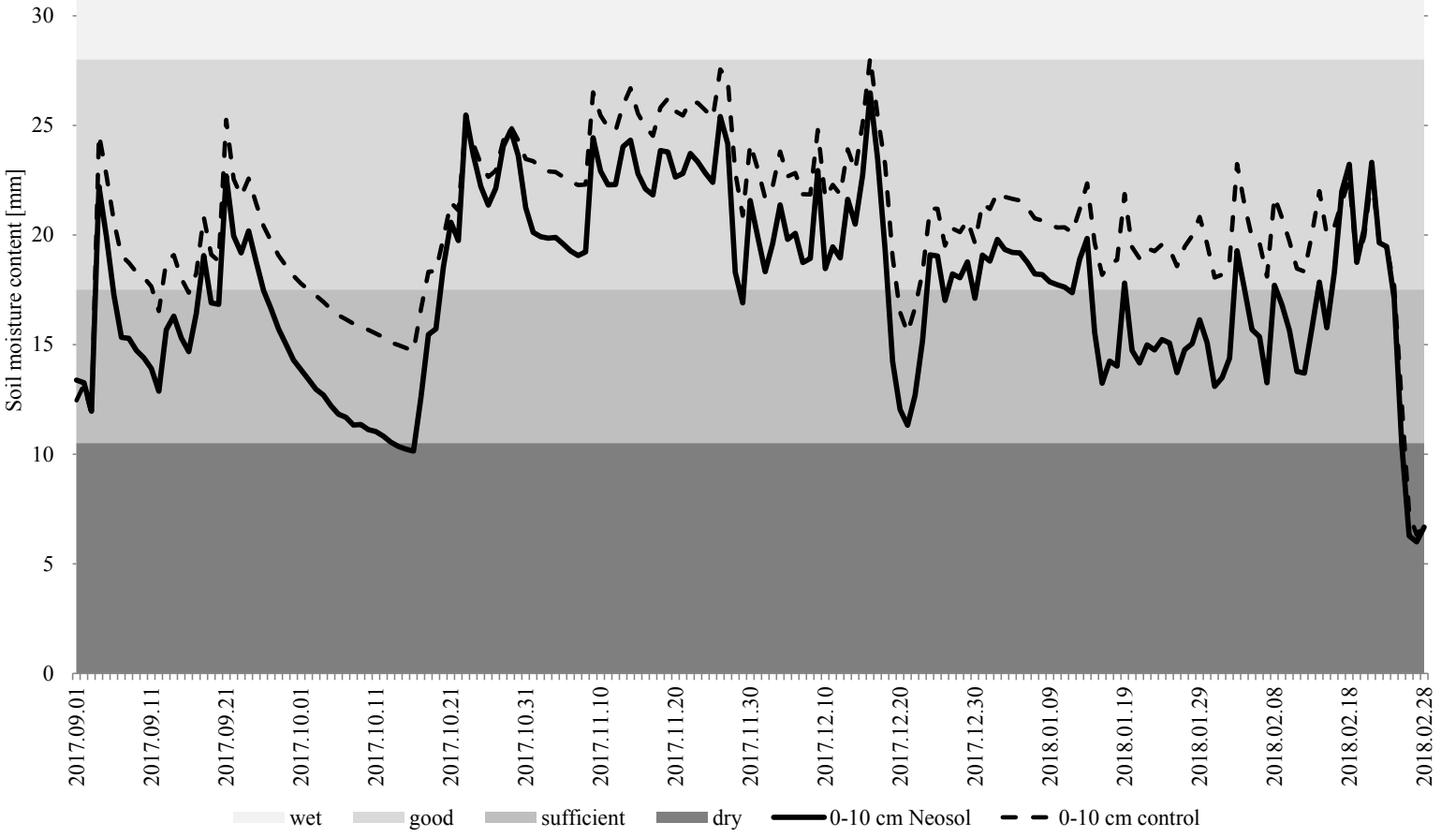

Figure 4. Change of soil moisture stocks in the $0-0.1 \mathrm{~m}$ soil layer in the AW season 
35

30

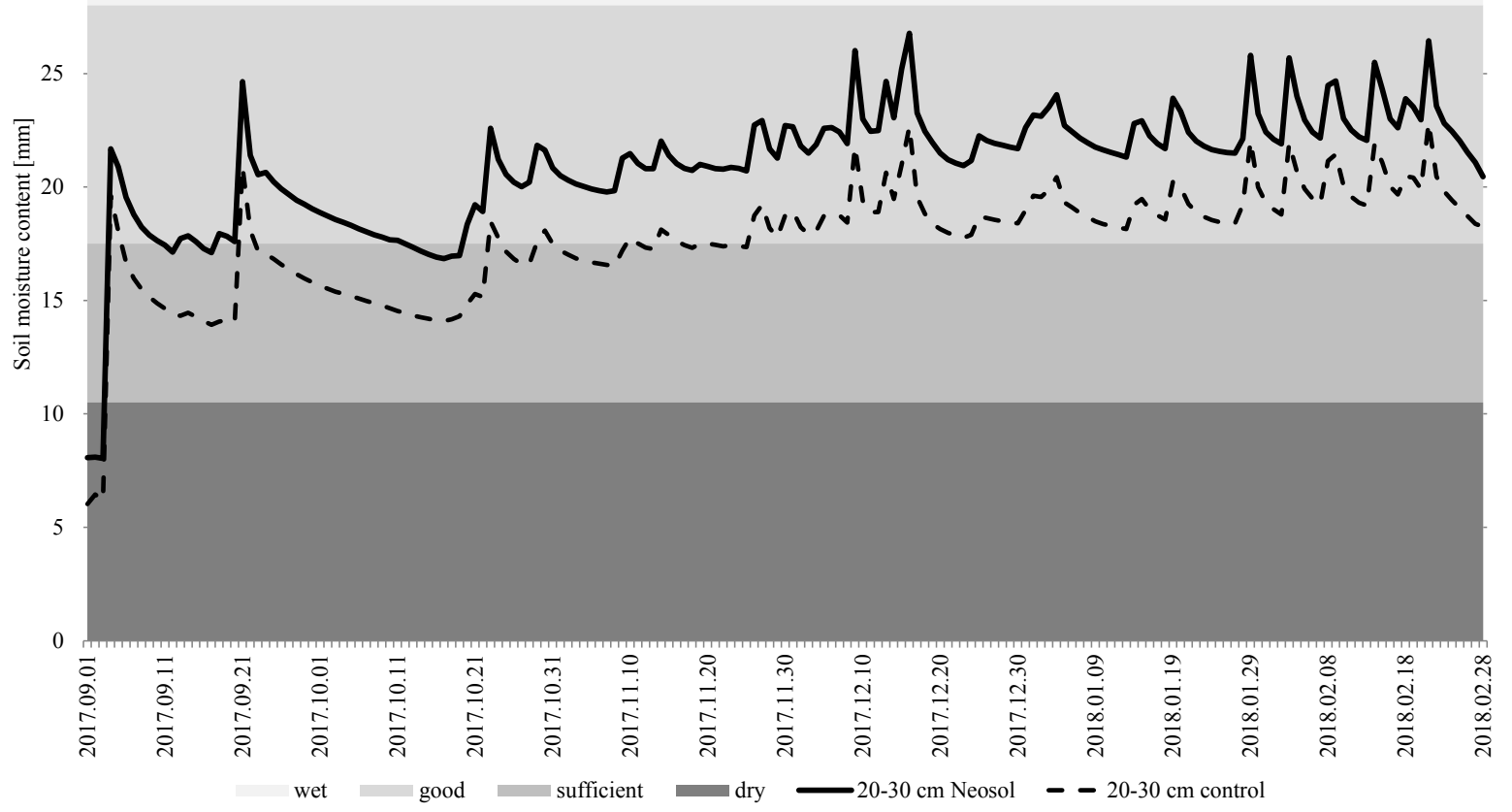

Figure 5. Change of soil moisture stocks in the $0.2-0.3 \mathrm{~m}$ soil layer in the AW season

70

60

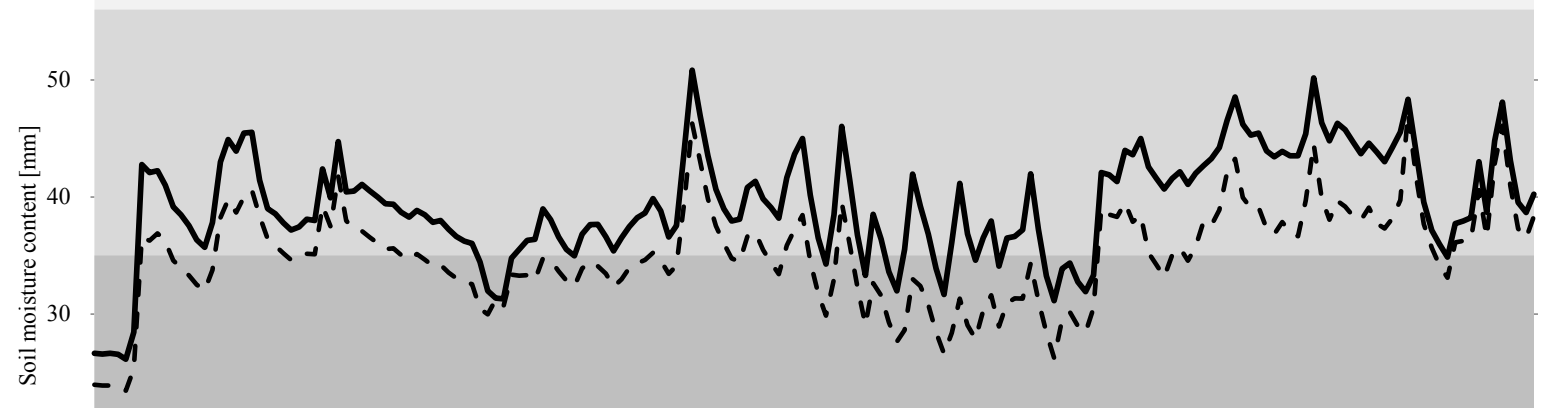

20

10

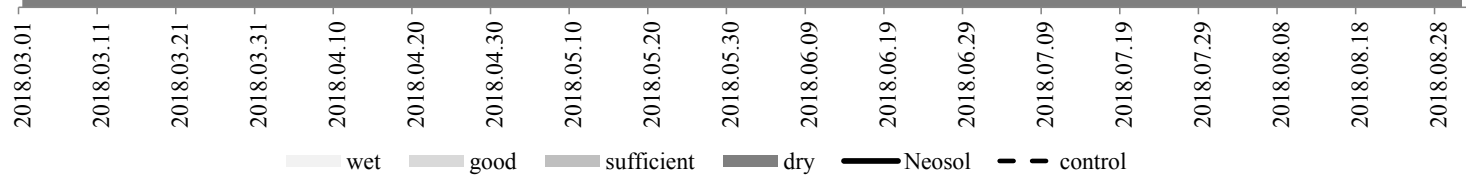

Figure 6. The sum of the soil moisture stocks of the two investigated soil layers in the SS season 
35

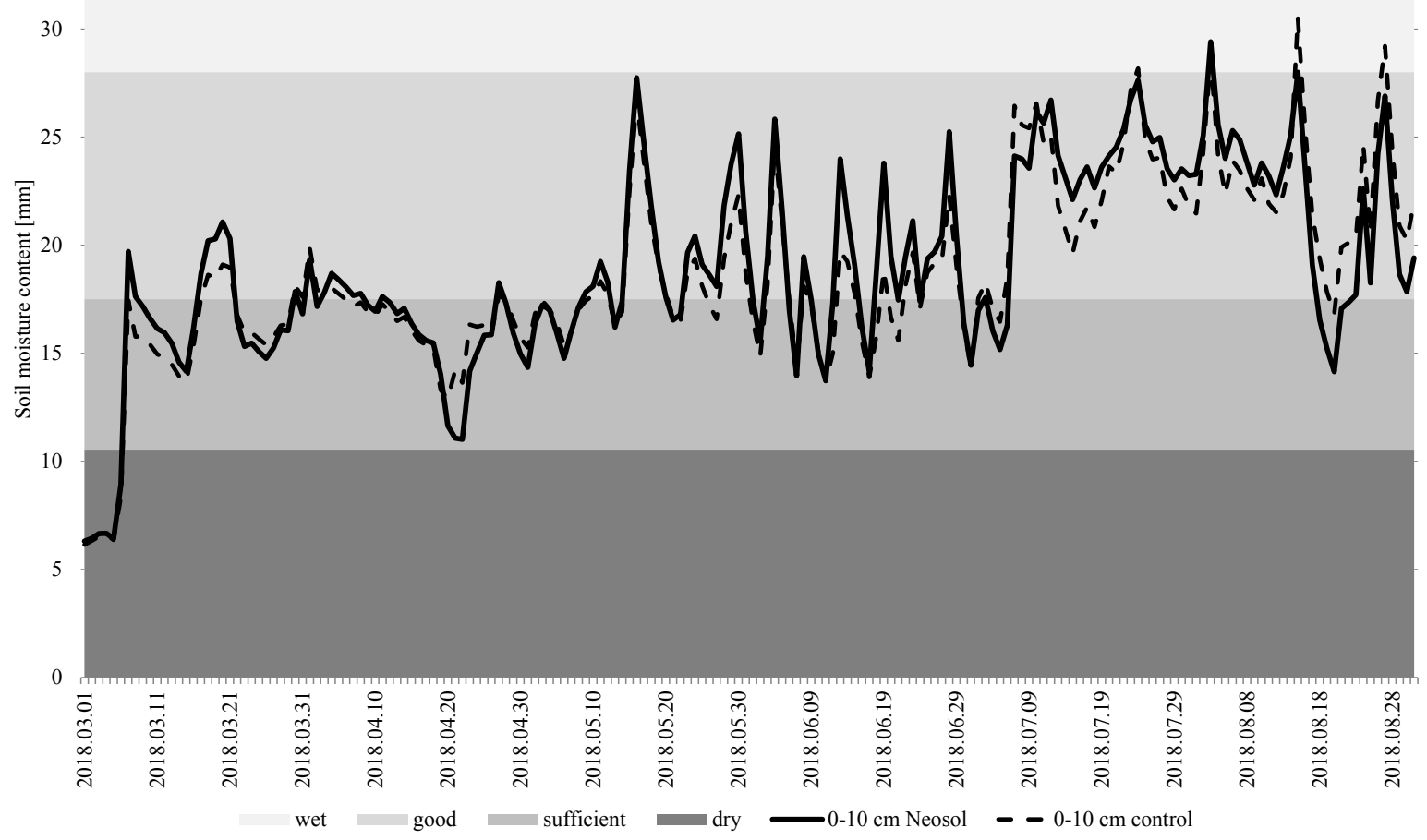

Figure 7. Change of soil moisture stocks in the $0-0.1 \mathrm{~m}$ soil layer in the $\mathrm{SS}$ season

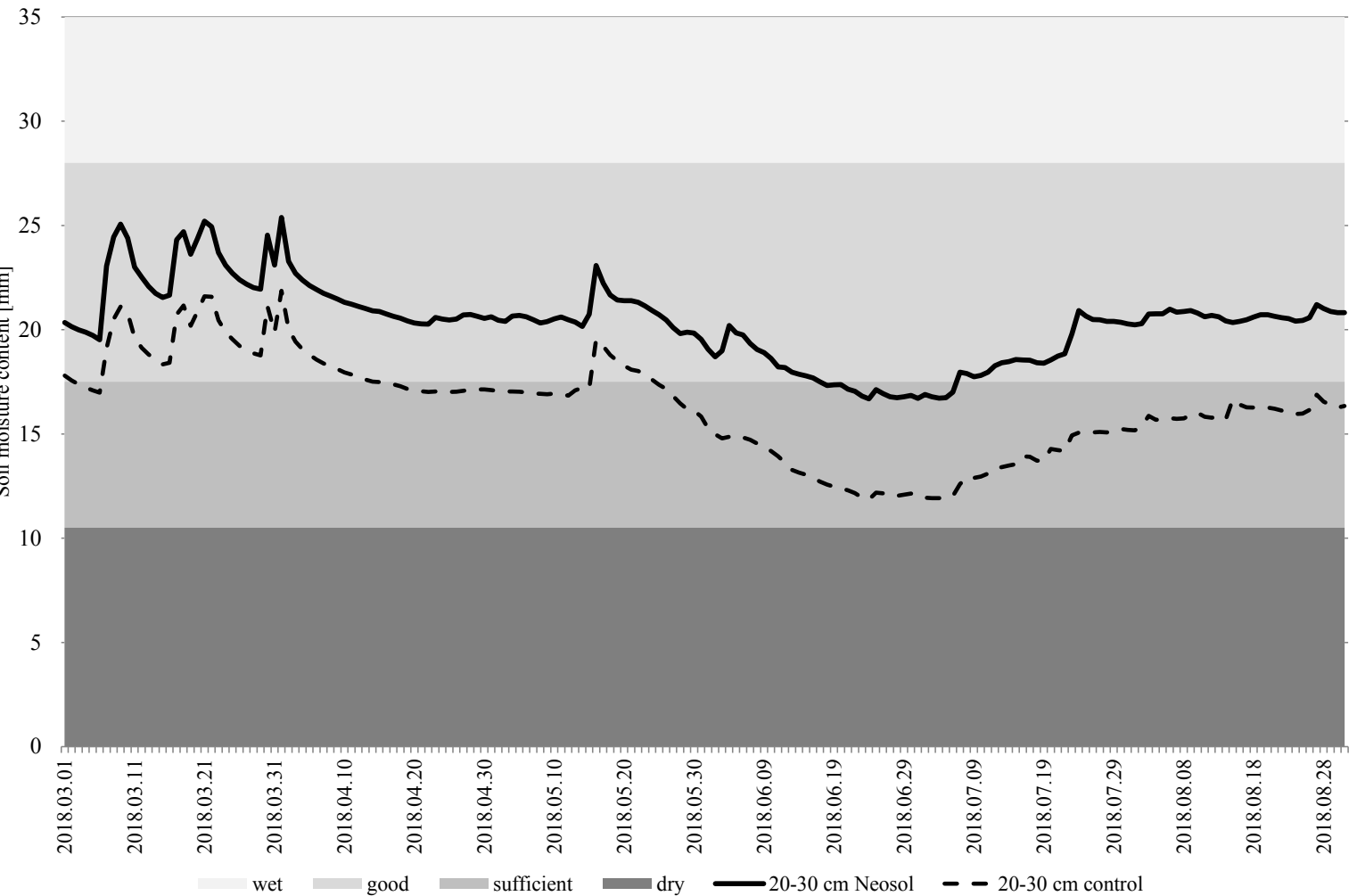

Figure 8. Change of soil moisture stocks in the $0.2-0.3 \mathrm{~m}$ soil layer in the SS season 
tion to it, on the salt content too. We supposed that the positive change in the soil structure resulting in the re-stratification of the water profile also effects on the salt content and profile of the soil. Due to the application of Neosol for a longer term, we expected better leaching features, therefore the downward movement of the salts resulting in better growing environment for the crops in the root zone, even under irrigation with saline water. We did not consider secondary salinization avoidable, but we aimed to mitigate its harmful effects by the application of soil conditioning.

After 6 years of application of Neosol, we took soil samples from each lysimeter after the irrigation season of 2018. On the base of the laboratory analyses of the soil samples, we calculated the total soluble salt contents of the top five $10 \mathrm{~cm}$ deep layers of the soils of each lysimeter taking the soil mass [g] of each $10 \mathrm{~cm}$ deep soil layer and its $[\mathrm{m} / \mathrm{m} \%]$ salt content into account. We compared these values to the original salt content when no saline water was irrigated. The results shown in Figure 9 originate from the average (mixed) soil samples of 3-3 lysimeters according to the water quality and the application of the soil conditioner.

Comparing to the original salt content of the soil (indicated with a horizontal line in the graphs), it can be concluded that leaching (negative salt balance) was characteristic to the lysimeters irrigated with deionised water due to the fact that no salts got into the soil. Nevertheless $5.2 \%$ less salt was found in the top $50 \mathrm{~cm}$ of the soil in the case of soil conditioning than in the control soil.
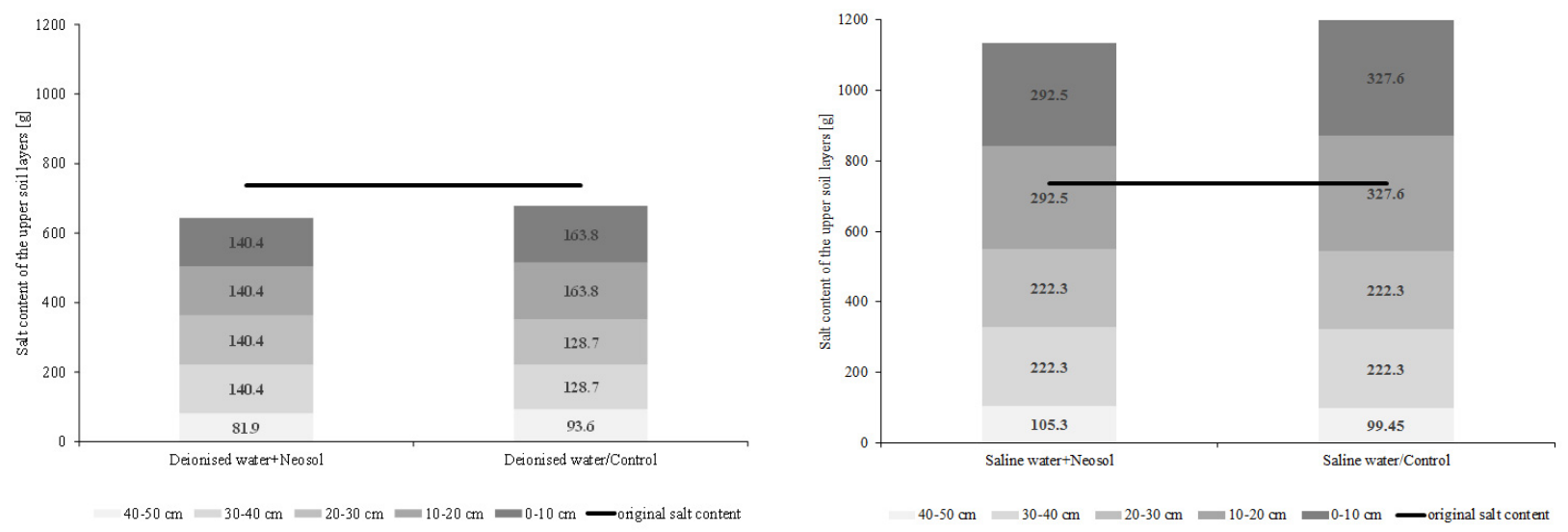

Figure 9. Effect of soil conditioning on the salt profile of the soil under irrigation with deionised and saline $(1,600 \mathrm{mg} / \mathrm{l}) \mathrm{water}$, Karcag 2018 
fore it was not a limiting factor in the point of view of germination.

The difference we found in the stratification of the same moisture content between the treatments can be considered a very positive effect of soil conditioning as the moisture profile (vertical distribution of the same amount of water) characteristic to the treated soil can be considered water preserving: through the higher infiltration and percolation rate, less unproductive evaporation loss takes place in the hot months.

On the base of our results, we established that the long-term and regular application of Neosol the porosity and water holding capacity of the soil can be increased; all these are manifested in the more favourable water supply in the root zone in the dry and hot months.

In harmony with the results of Borowiak et al. (2016), Sulewska et al. (2016) and Wojciechowski (2015), improved soil status could be achieved by means of the application of Neosol. In close correlation with the water regime of the soil (based on the improved soil structure), slight mitigation of the harmful effect of secondary salinization can be figured out, but this effect is highly dependent of the total annual salt load gets into the soil through irrigation.

\section{CONCLUSIONS}

On the base of our results it can be concluded that soil conditioning is recommended in order to improve the status of salt affected or potentially salt affected soils susceptible for secondary salinization with unfavourable water regime as the harmful effects of irrigation with saline water can be mitigated. We found Neosol to be a prospective soil conditioner, it was proved that its application has positive effect on the water and salt regime of the soil, partly by creating a more favourable vertical distribution of the soil water, and partly preserving more moisture in the soil.

The soil structure improving effect of Neosol was also manifested in the salt profile of the soil, the harmful salt causing secondary salinization were leached down to the deeper $(0.4-0.5 \mathrm{~m})$ layers providing "saltless" environment for the development of the crops in the main root zone.

Soil conditioning, combined with the optimization of irrigation (control of quantity, frequency), is highly recommended for areas with unfavourable agroecological conditions as the safety of crop production can be increased.

Acknowledgements. The research was financed by the Higher Education Institutional Excellence Programme (20428-3/2018/FEKUTSTRAT) of the Ministry of Human Capacities in Hungary, within the framework of the 4 . thematic programme of the University of Debrecen.

\section{REFERENCES}

ABDUL, R. - MAHMOOD, K. 2012. Rehabilitation of saline ecosystems through cultivation of salt tolerant plants. In $\mathrm{Pa}$ kistan Journal of Botany, vol. 44(SI), pp. 69-75.

ASGHAR, H.N. - SETIA, R. - MARSCHNER, P. 2012. Community composition and activity of microbes from saline soils and non-saline soils respond similarly to changes in salinity. In Soil Biology and Biochemistry, vol. 47, pp. $175-178$.

BARDAJI, J. 1974. Los suelos de regadío. In Agricultura: Revista Agropecuaria y Ganadera, no. 504, pp. 227-231. ISSN 0002-1334

BLASKÓ, L. 2005. Talajromlási folyamatok és mérséklési lehetőségeik a Tiszántúl kötött talajain. MTA doktori értekezés.

BLASKÓ, L. - ZSEMBELI, J. 2008. Study of salinization in different climatic and hydrologic situations in lysimeters. In 2nd Workshop - Lysimeters for Global Change Research : Biological Processes and the Environmental Fate of Pollutants. April 23-25, GSF - National Research Centre for Environment and Health Institute of Soil Ecology, München.

BOROWIAK, K. - NIEWIADOMSKA, A. - SULEWSKA, H. - SZYMANSKA, G. - GLUCHOWSKA, K. - WOLNA-MARUWKA, A. 2016. Effect of PRP SOL and PRP EBV nutrition on yield, photosynthesis activity and soil microbial activity of three cereal species. In Fresenius Environmental Bulletin, vol. 25, no. 6, pp. 2026-2035.

ENCISO, J. - MULTER, W. - COLAIZZI, P 2002. Irrigating cotton with salty water and Subsurface Drip Irrigation. In Written for presentation at the 2002 ASAE Annual International Meeting/CIGR XVth World Congress Sponsored by ASAE and CIGR. Hyatt Regency Chicago.

FILEP, GY. 1999. A talajok vízgazdálkodása. In STEFANOVITS. P. - FILEP, GY. - FÜLEKY, G. (Eds.) Talajtan (Soil Science). Budapest : Mezőgazda Kiadó, pp.153-169.

KAMAN, H. - KURUNÇ, A. - DEMIR, H. - TEZCAN, A. - SAYICI1, A. - CAN, M. - GÖKÇEN, U. 2017. Salinity change in different soil layers of tomato irrigated with salty water. In International Journal of Plant \& Soil Science, vol. 19 , no. 5 , pp. $1-6$.

SULEWSKA, H. - KOZIARA, W. - SZYMAŃSKA, G. NIEWIADOMSKA, A. - PANASIEWICZ, K. - RATAJCZAK, K. 2016. Response of spring barley to PRP SOL application as a complex of mineral inducer process (MIP). In Nauka Przyroda Technologie, vol. 10, no. 2, pp. 17. 
ZSEMBELI, J. - SZÜCS, L. - BLASKÓ, L. 2011. Secondary salinization by irrigation from drilled wells in Karcag area. In Növénytermelés, vol. 183, no. 3, pp. 305-308.

I1: http://www.prp-technologies.eu/en/products-and-services/ our-products/Neosol (12/03/2019)
I2: https://www.ugt-online.de/en/products/soil-science/soilmoisture/smt-100 (19/10/2018)

Received: March 18, 2019 Accepted: June 6, 2019 